\title{
Theoretical aspects on local alkalinization following hydrolysis of deep-placed urea in paddy soils under transplanting
}

\author{
Rémi GAUDIN \\ Montpellier SupAgro, UMR System 2 place Viala, 34060 Montpellier France. \\ E-mail: remi.gaudin@supagro.fr; Phone: +33 49961 2059; Fax: +33 499613034
}

\begin{abstract}
Urea broadcasting in rice cultivation often leads to ammonia volatilization because the hydrolysis reaction of urea quickly gives ammonium, ammonia and bicarbonate. Particularly ammonia $\left(\mathrm{NH}_{3}\right)$ is subject to emanation which can be avoided if urea is deep placed. This no loss optimistic scenario is realized by strict positioning of urea supergranules in the anaerobic layer of the paddy soil. In this study, we wanted to verify if the development of alkalinity in the site of placement could be predicted from the chemical equilibria in soil solution, neglecting the effect(s) of the soil matrix. Calculation of $\mathrm{pH}$ related to ammoniacal $\mathrm{N}$ concentration was performed considering the main acid-basic equilibria taking place within the soil solution. Data were compared to localized $\mathrm{pH}$ and ammoniacal $\mathrm{N}$ values obtained in two paddy fields following deep placement of urea supergranules. The $\mathrm{pH}$ never trespassed 9.25 which is the $\mathrm{pK}_{\mathrm{a}}$ of ammonia, in theoretical terms as well in the localized point placement sites in the fields. The linear relationship between log of ammoniacal $\mathrm{N}$ concentration and $\mathrm{pH}$ seems to indicate a strong influence of the cation exchange capacity so far not taken into account by the model. Urea supergranules are compared to mini-bombs of $\mathrm{NH}_{3}$; to prevent any leak to the floodwater (then to the atmosphere) they have to be buried with precision.
\end{abstract}

(C) 2019 International Formulae Group. All rights reserved.

Keywords: Point placement, urea supergranule, generated alkalinity, wetland soil, soil solution, $\mathrm{pH}$.

\section{INTRODUCTION}

Urea is the main nitrogen fertilizer used in rice cultivation. In developing countries, the $\mathrm{N}$ application rate can be moderate when in some regions of China or India fields are receiving large amounts of urea. High yields (around 8 to $10 \mathrm{Mg}$ per ha) and even intermediate yields are often associated with detrimental effects on the environment. The main mechanism inflicting loss is ammonia volatilization draining a huge flux of $\mathrm{N}$ towards the atmosphere.
When urea is broadcasted at puddling time, it quickly dissolves in the mud or in the floodwater. Hydrolysis follows at a very high speed so that less than a few days after urea application, the ammoniacal nitrogen is the dominant form of $\mathrm{N}$ in the floodwater. The hydrolysis reaction generates the ammonium ion $\mathrm{NH}_{4}{ }^{+}$and ammonia molecule $\mathrm{NH}_{3}$ in equal quantities, together with the bicarbonate anion $\left(\mathrm{HCO}_{3}{ }^{-}\right)$. It drives an alkalinization of the floodwater (Yao et al., 2018; Zhang et al., 2017). The ammonium concentration and $\mathrm{pH}$ 
are then following similar patterns in relation with the time of urea application, quantity of applied urea and other factors influencing the floodwater depth (rain, drainage). However the suspected link between the ammoniacal $\mathrm{N}$ concentration and the $\mathrm{pH}$ of the floodwater is difficult to assess because another factor plays in. During daytime alga abstracts carbon dioxide from the floodwater and contributes to $\mathrm{pH}$ augmentation, notably when temperature is favorable to algal growth. The consequence is an important $\mathrm{N}$ loss by ammonia volatilization (Koudjega et al., 2019). To avoid it, researchers in numerous countries have successfully tested urea deep placement in wetland rice cultivation (Bautista et al., 2001; Kapoor et al., 2008; Bandaogo et al., 2015, 2018; D’Onofrio et al., 2018; Koudjega et al., 2019) or for rainfed crops (Rochette et al., 2013).

In this manuscript, we shall try to establish a theoretical link between the $\mathrm{pH}$ and the ammoniacal $\mathrm{N}$ concentration at the site of urea point placement, around 7-10 $\mathrm{cm}$ below the soil surface. The chemical equilibrium reactions of ammonia and carbon dioxide with water will be used to obtain the theoretical values of ammoniacal nitrogen concentration corresponding to selected values of $\mathrm{pH}$ in a range between 8 and the $\mathrm{pK}_{\mathrm{a}}$ of ammonia. These couples (ammoniacal $\mathrm{N}$ concentration, $\mathrm{pH}$ ) will be compared with experimental data obtained in previous experiments on ammoniacal nitrogen diffusion and ammonia assimilation from deep placed urea supergranules (Gaudin and D’Onofrio, 2015).

\section{MATERIALS AND METHODS}

\section{Theoretical background}

The hydrolysis of urea is sometimes (in old textbooks) written as follows:

$\mathrm{CO}\left(\mathrm{NH}_{2}\right)_{2}+\mathrm{H}_{2} \mathrm{O}-------->\mathrm{CO}_{2}+2 \mathrm{NH}_{3}$ (1)

This presentation respects the stoechiometry of the reaction but it is evident that $\mathrm{CO}_{2}$ (or $\mathrm{H}_{2} \mathrm{CO}_{3}$ ) and $\mathrm{NH}_{3}$ cannot be at the same time the dominant chemical species of the carbonates and ammoniacal $\mathrm{N}$ because their importance is respectively linked to acid (for $\mathrm{CO}_{2}$ ) or very alkaline conditions (for $\mathrm{NH}_{3}$ ).

Another presentation was adopted in Rachhpal-Singh and Kirk (1993):

$$
\mathrm{CO}\left(\mathrm{NH}_{2}\right)_{2}+3 \mathrm{H}_{2} \mathrm{O}-------->2 \mathrm{NH}_{4}{ }^{+}+\mathrm{HCO}_{3}{ }^{-}
$$$$
+\mathrm{OH}^{-}
$$

The following writing has been proposed in Gaudin and Dupuy (1999):

$\mathrm{CO}\left(\mathrm{NH}_{2}\right)_{2}+2 \mathrm{H}_{2} \mathrm{O}$--------> $\mathrm{HCO}_{3}^{-}+\mathrm{NH}_{4}{ }^{+}$ $+\mathrm{NH}_{3}$

This formulation has two advantages. First the neutral molecule $\mathrm{NH}_{3}$ can play an important role in the equilibrium. Secondly it could be the case for $\mathrm{HCO}_{3}^{-}$which is the dominant form of carbonates within the 6.37 to 10.25 $\mathrm{pH}$ range.

The ammonium $\left(\mathrm{NH}_{4}{ }^{+}\right)$and ammonia $\left(\mathrm{NH}_{3}\right)$ species are submitted to the acid-basis equilibrium written either as (3) or (4):

$$
\begin{aligned}
& \mathrm{NH}_{3}+\mathrm{H}_{2} \mathrm{O}<-------->\mathrm{NH}_{4}^{+}+\mathrm{OH}^{-} \\
& \mathrm{NH}_{4}^{+}+\mathrm{H}_{2} \mathrm{O}<-------->\mathrm{NH}_{3}+\mathrm{H}_{3} \mathrm{O}^{+}
\end{aligned}
$$

The constants of these reactions are respectively $\mathrm{K}_{\mathrm{b}}$ and $\mathrm{K}_{\mathrm{a}}$ :

$\mathrm{K}_{\mathrm{b}}=\left(\mathrm{NH}_{4}^{+}\right)\left(\mathrm{OH}^{-}\right) /\left(\mathrm{NH}_{3}\right)=1.774 \times 10^{-5}$ at $25^{\circ} \mathrm{C}$

$\mathrm{K}_{\mathrm{a}}=\left(\mathrm{NH}_{3}\right)\left(\mathrm{H}_{3} \mathrm{O}^{+}\right) /\left(\mathrm{NH}_{4}^{+}\right)=5.637 \times 10^{-10}$ at $25^{\circ} \mathrm{C} \quad$ (6)

(Numerical values from classical Handbook of Chemistry and Physics)

The corresponding constants on the cologarithm scale are $\mathrm{pK}_{\mathrm{b}}(=4.75)$ and $\mathrm{pK}_{\mathrm{a}}(=$ 9.25) which are linked by:

$\mathrm{pK}_{\mathrm{a}}+\mathrm{pK}_{\mathrm{b}}=14$

For carbonates the acid-basic reactions are:

$$
\begin{aligned}
& \mathrm{H}_{2} \mathrm{CO}_{3}+\mathrm{H}_{2} \mathrm{O}<------->\mathrm{HCO}_{3}{ }^{-}+\mathrm{H}_{3} \mathrm{O}^{+} \\
& \mathrm{K}_{\mathrm{a} 1}=\left(\mathrm{HCO}_{3}\right)\left(\mathrm{H}_{3} \mathrm{O}^{+}\right) /\left(\mathrm{H}_{2} \mathrm{CO}_{3}\right)=4.30 \times 10^{-7} \\
& \left(\mathrm{pK}_{\mathrm{a} 1}=6.37\right) \quad(9) \\
& \mathrm{HCO}_{3}{ }^{-}+\mathrm{H}_{2} \mathrm{O}<------->\mathrm{CO}_{3}{ }^{2-}+\mathrm{H}_{3} \mathrm{O}^{+} \quad(10) \\
& \mathrm{K}_{\mathrm{a} 2}=\left(\mathrm{CO}_{3}{ }^{2-}\right)\left(\mathrm{H}_{3} \mathrm{O}^{+}\right) /\left(\mathrm{HCO}_{3}{ }^{-}\right)=5.61 \times 10^{-11} \\
& \left(\mathrm{pK}_{\mathrm{a} 2}=10.25\right) \quad(11)
\end{aligned}
$$

The $\mathrm{H}_{2} \mathrm{CO}_{3}$ concentration in water is given by the Henry's law:

$$
\left(\mathrm{H}_{2} \mathrm{CO}_{3}\right)=\mathrm{K}_{\mathrm{s}} \times\left(\mathrm{P}_{\mathrm{CO} 2}\right)
$$


$\mathrm{K}_{\mathrm{s}}$ being the solubility of $\mathrm{CO}_{2}$ in mol. $\mathrm{L}^{-1}$ and $\left(\mathrm{P}_{\mathrm{CO} 2}\right)$ designating the ratio of partial pressure of $\mathrm{CO}_{2}$ to the atmospheric pressure.

We followed Nye (1972) for the value of $\mathrm{K}_{\mathrm{s}}$. In a review on the constant of Henry found in the litterature, Sander (2015) gives values ranging from 0.0314 to 0.0456 mol. $\mathrm{L}^{-1}\left(3.1\right.$ to $4.5 \times 10^{-4}$ mol.m $\mathrm{m}^{-3} \cdot \mathrm{Pa}^{-1}$ exactly).

$\mathrm{K}_{\mathrm{s}}=0.03736$ mol. $\mathrm{L}^{-1} \quad$ (13).

In a paddy soil, $\mathrm{P}_{\mathrm{CO} 2}$ increases after the puddling and flooding operations. In relation with the progressive installation of anaerobic conditions within the soil, the concentrations of $\mathrm{O}_{2}$ and $\mathrm{CO}_{2}$ tend to be inversely related with a decrease in $\mathrm{O}_{2}$ accompanied by an increase in $\mathrm{CO}_{2}$ concentration (Don Scott et al., 2003). The higher values of $\mathrm{P}_{\mathrm{CO} 2}$ are registered one week after puddling then decreases and stabilized around 0.05 to 0.2 atmosphere (Ponnamperuna, corresponding to 5\% and 20\% of $\mathrm{P}_{\text {atm }}$ (For full understanding $\mathrm{P}_{\mathrm{atm}}$ indicates the normal pressure of atmosphere).

Suppose the urea-N concentration to be c within an insulated volume before hydrolysis. If we admit full hydrolysis of this urea, the three following equations will be valid, the first one for electroneutrality and the two other ones for conservation of ammoniacal $\mathrm{N}$ and carbonates, respectively:

$\left(\mathrm{H}_{3} \mathrm{O}^{+}\right)+\left(\mathrm{NH}_{4}^{+}\right)=\left(\mathrm{HCO}_{3}{ }^{-}\right)+2\left(\mathrm{CO}_{3}{ }^{2-}\right)+$ $\left(\mathrm{OH}^{-}\right) \quad(14)$

$\left(\mathrm{NH}_{4}^{+}\right)+\left(\mathrm{NH}_{3}\right)=\mathrm{c}$

$\left(\mathrm{H}_{2} \mathrm{CO}_{3}\right)+\left(\mathrm{HCO}_{3}{ }^{-}\right)+\left(\mathrm{CO}_{3}{ }^{2-}\right)=\mathrm{c} / 2+\mathrm{s}(\mathrm{CO})$ (16)

With $\mathrm{s}(\mathrm{CO})$ designating the sum of carbonates concentrations before urea hydrolysis, calculated with the initial $\mathrm{P}_{\mathrm{CO} 2}$ and admitting an initial $\mathrm{pH}=7$.

The soil was considered at neutrality. This trend towards neutrality results from the numerous chemical reactions taking place within the soil after submergence (Yoshida, 1981; De Giudicci, 1993). This neutral state is more rapidly attained in old paddy soils than in soils recently converted to wetland agriculture.

To solve these equations, we first calculated $\mathrm{s}(\mathrm{CO})$ with (12), (11), (9) for $\mathrm{P}_{\mathrm{CO} 2}=0.1 \mathrm{~atm}$ and for $\mathrm{P}_{\mathrm{CO} 2}=0.2 \mathrm{~atm}$.

In a second step, we worked with the following $\mathrm{pH}$ values: 9.1-9.0-8.8-8.6-8.4-8.28.0 and for each of these values we calculated $\left(\mathrm{NH}_{4}+\right)$ from equations (5) and (15).

For each of the $\mathrm{pH}$ value, we calculated $\left(\mathrm{H}_{2} \mathrm{CO}_{3}\right)$ from (16) and derived $\left(\mathrm{HCO}_{3}{ }^{-}\right)$and $\left(\mathrm{CO}_{3}{ }^{2-}\right)$ from (9) and (11).

We then equalized the left and right sides of (14).

The results were theoretical pairs $(\mathrm{pH}, \mathrm{c})$ values for the two chosen $\mathrm{P}_{\mathrm{CO} 2}$.

\section{Experiments}

Experimental data on $\mathrm{pH}$ and ammoniacal nitrogen concentrations were part of a large set of results from a study describing the diffusion and assimilation of ammoniacal $\mathrm{N}$ after urea deep placement (Gaudin and D'Onofrio, 2015). It was performed in two paddy fields on the highland of Madagascar. The data were obtained in the sites of point placement $(2 \mathrm{~g}$ and $4 \mathrm{~g}$ urea supergranules) by applying vacuum to small solution samplers (one sampler attached to one urea supergranule at the time of placement), and collecting soil solution at different times. Ammoniacal $\mathrm{N}$ and $\mathrm{pH}$ determinations were practised at Laboratoire des Radioisotopes of Antananarivo. They involved indophenol blue reaction for ammoniacal $\mathrm{N}$ and the classical electrometric method for $\mathrm{pH}$.

Only data reporting ammoniacal nitrogen concentration greater than 0.01 molar have been selected here. As the sampler is placed within the ammonium /ammonia rich central zone where the process of diffusion drives the $\mathrm{N}$ concentration until a level of 0.01 $\mathrm{M}$ ammoniacal $\mathrm{N}$ is attained (Gaudin and Dupuy, 1999; Gaudin et al., 2016) this gives insurance that ammonium /ammonia uptake 
and assimilation did not influence the measured $\mathrm{pH}$.

\section{RESULTS}

The graphical representation (Figure 1) clearly indicates different patterns for the theoretical and experimental link between $\mathrm{pH}$ and the logarithm of ammoniacal $\mathrm{N}$ concentration. However, these patterns share a common zone in the top part of the studied $\mathrm{pH}$ range. The points from experimental data are relatively well aligned, forming a tangent to the theoretical curve for $\mathrm{P}_{\mathrm{CO} 2}=0.2$ atm around $\mathrm{pH}=8.8$. It intersects with the curve for $\mathrm{P}_{\mathrm{CO} 2}$ $=0.1 \mathrm{~atm}$ at $\mathrm{pH}=8.3$ and for another value of $\mathrm{pH}$ around $\mathrm{pH}=9.2$ (data not shown).
The theoretical curves have an upward concavity, a property which is not exhibited by the experimental data. This concavity is associated with an asymptotic trend for the highest value of $\mathrm{pH}$ to not trespass the $\mathrm{pK}_{\mathrm{a}}$ of ammonia: for the curves corresponding to the two $\mathrm{P}_{\mathrm{CO} 2}$ values, the vertical line $\mathrm{pH}=\mathrm{pK}_{\mathrm{a}}=$ 9.25 is clearly a limit related to the equations of the model. The left part of the curves is less simple to explain in theoretical terms.

The maximum observed $\mathrm{pH}$ is 9.20 (near the $\mathrm{pK}_{\mathrm{a}}$ of ammonia). Below this value, there is a linear relationship between $\log \mathrm{c}$ and $\mathrm{pH}$. The slope of the corresponding line equation is 1.147 thus exceeding 1 by $15 \%$.

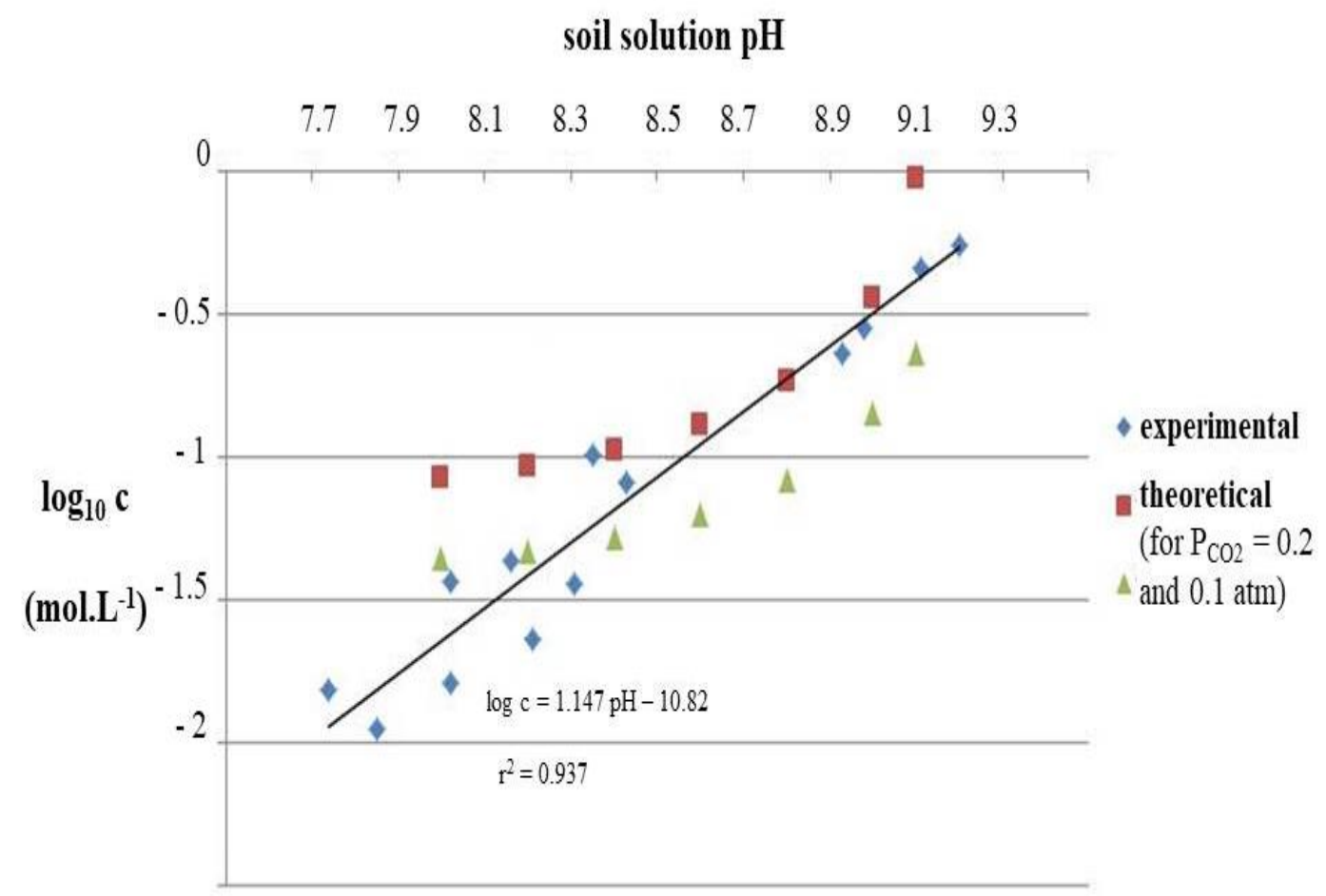

Figure 1: Experimental and theoretical relationships between $\mathrm{pH}$ and decimal logarithm of ammoniacal $\mathrm{N}$ concentration. The series of theoretical values are based on initial $\mathrm{P}_{\mathrm{CO} 2}$ of $0.2 \mathrm{~atm}$ (red) and $0.1 \mathrm{~atm}$ (green). The linear relationship (experimental points) is very highly significant (probability $<0.001$ ) 


\section{DISCUSSION}

We can consider that agreement between theory and observation to be good where on Figure 1 observed points are between the theoretical points corresponding to the two $\mathrm{P}_{\mathrm{CO} 2}$. This is the case for 6 observations, in the 8.35 to $9.25 \mathrm{pH}$ range. Below a pH around 8.3 the observed points are following a tendency to align in straight direction.

This alignment of experimental points constitutes a surprising result and one possible explanation is that it is imposed by the soil matrix, notably the organic matter and the clay content of the soil. The humus has numerous carboxylic groups and it is plausible that the exchange of ammonium between the organo-mineral (humus + kaolinite) matrix and the soil solution should be the factor driving this linearity.

Pelster et al. (2019) have observed that ammonia volatilization from subsurface band application of urea is less active in soils with a high clay content, then with a higher cation exchange capacity. It means that ammonium in exchangeable position has not the same behavior that the mixture of ammonium and molecular ammonia in soil solution. The same tendency of clayed soils to limit ammonia volatilization has been observed by Koudjega et al. (2019) in the case of urea granules positioned at small depth. As attended, Koudjega et al. (2019) obtained the best agronomic results for placement of the fertilizer at $8 \mathrm{~cm}$ or $12 \mathrm{~cm}$ deep in comparison with shallower positioning. They recommended $8 \mathrm{~cm}$ for practice in the field. At this depth, for the first few days to one week after granule placement, most of the ammoniacal nitrogen deriving from urea hydrolysis is constitutive of an alkaline solution, with approximately equal concentrations of molecular ammonia, ammonium and bicarbonate, occupying a spherical volume centered on the placement point. The peak of alkalinity $(\mathrm{pH}=9.0)$ is classically reported at 3 days for $1 \mathrm{~g}$ granule when in this work the maximum $\mathrm{pH}(=9.20)$ happened at 4 days for $4 \mathrm{~g}$ granule. After this peak corresponding to full hydrolysis of urea, ammoniacal $\mathrm{N}$ distribution changes according to the mathematics of diffusion complexified by a slowdown-exchange effect (Gaudin and D'Onofrio, 2015) and the alkalinity of the central core diminishes quitely at a similar pace. It is then possible to formulate the idea of a central alkaline volume as being trapped, if the supergranule is well positioned at depth, in a huge bulk of soil in neutral condition. In other words, urea supergranules are minibombs of ammonia which cannot liberate $\mathrm{NH}_{3}$ in the floodwater (and from there in the atmosphere) if they are correctly placed in the soil. The $\mathrm{NH}_{3}$ content of these mini-bombs is naturally proportional to the mass of the supergranules.

The slope of the relation between $\log \mathrm{c}$ and $\mathrm{pH}$ is 1.147 which is not so different from 1. A unit value has been observed in numerous studies concerned with the exchange of $\mathrm{NH}_{4}^{+}$with $\mathrm{H}_{3} \mathrm{O}^{+}$. But the main focus of these studies is often exchange or transport across biological membranes, so the analogy can be too speculative. To understand the supposedly unit slope between $\log \mathrm{c}$ and $\mathrm{pH}$, it should be necessary to add equation(s) related to the exchange of ammoniacal nitrogen between the soil matrix and soil solution. To succeed in this task, the exchange isotherm had to be investigated.

\section{Conclusion}

For calculation, we have supposed the chemical equilibria taking place in soil solution, neglecting any effect of the soil matrix. The experimental couples $(\mathrm{pH}$, ammoniacal $\mathrm{N}$ concentration) were close to the theoretical ones for the highest concentrations, with $\mathrm{pH}$ approaching $\mathrm{pK}_{\mathrm{a}}$ of ammonia (9.25). A linear relationship between the $\log$ of ammoniacal $\mathrm{N}$ concentration and $\mathrm{pH}$ was put in evidence. This relationship indicates the strong influence of other(s) factor(s) not taken into account by our model. One major factor is plausibly the total exchange capacity of the paddy soils, related to the clay (kaolinite in this case) and organic matter contents. For higher ammoniacal N 
concentrations, this matrix should be saturated (replenished exchange capacity) and the saturated soil should adopt a behavior not very different from a rich soil solution containing ammonium, molecular ammonia and bicarbonate at high and equal concentrations. By applying urea supergranule deep in paddy fields, researchers have experimented the alkaline power of urea. The bowls of urea are mini-bombs of $\mathrm{NH}_{3}$. To avoid any loss of gaseous ammonia in the environment, it is imperative to bury them correctly. Using the image of the mini-bomb in messages towards the rice growers could help them to understand the paradoxical nature of urea (highly soluble in water, apparently neutral, but rapidly generating volatile base $\mathrm{NH}_{3}$ and ammonium ion in equal molarity) to target a good management of the quantity they apply.

\section{COMPETING INTERESTS}

The author declares that he has no competing interests.

\section{AUTHORS' CONTRIBUTIONS}

RG has made the theoretical and practical chemistry reported in this work.

\section{ACKNOWLEDGEMENTS}

The author is grateful to Samuel Randrianarison, retired civil servant from Madagascar University, for having monitored soil solution extraction in the paddy fields.

\section{REFERENCES}

Bandaogo A, Bidjokjazo F, Youl S, Safo E, Abaidoo R, Andrews R. 2015. Effect of fertilizer deep placement with urea supergranule on nitrogen use efficiency of irrigated rice in Sourou Valley (Burkina Faso). Nutr. Cycl. Agroecosyt., 102: 7-89. DOI: 10.1007/s10705-0149653-6

Bandaogo AA, Serme I, Bama NAD, Ouattara K, Bidjokadjo F, Youl S. 2018. Ammonia assessment in irrigated rice system after nitrogen fertilizers application. Journal of Agriculture and
Environmental Sciences, 7(2): 64-70. DOI: 10.15640/jaes.v7n2a7

Bautista EU, Koike M, Suministrado DC. 2001. Mechanical deep placement of nitrogen in wetland rice. J. Agric. Engng. Res., $\quad 78(4): \quad 333-346 . \quad$ DOI: 10.1006/jaer.2000.0675

De Giudicci P. 1993. Caractérisation physicochimique des sols rizicultivés d'un basfond des hautes terres de Madagascar : variabilité topologique des paramètres et influence sur la productivité. In BasFonds et Riziculture, Raunet M (ed). CIRAD: Montpellier; 251-259.

Don Scott H, Miller DM, Renaud FG. 2003. Rice soils: Physical and chemical characteristics and behaviour. In Rice: Origin, History, Technology, and Production, Smith CW, Dilday RH (eds). John Wiley \& Sons: Hoboken, New Jersey; 297-329.

D’Onofrio G, Dupuy J, Gaudin R. 2018. Comparative effects of the application of urea prills and urea supergranules on flooded rice in Madagascar. Journal of Agricultural Studies, 6(1): 218-233. DOI: 10.5296/jas.v6i1.12741

Gaudin R, Dupuy J. 1999. Ammoniacal nutrition of transplanted rice fertilized with large urea granules. Agron. J., 91: 33-36.

DOI: https://dl.sciencesocieties.org/publication s/aj/pdfs/91/1/AJ0910010033

Gaudin R, D'Onofrio G. 2015. Is the sourcesink relationship in transplanted rice receiving deep-placed urea supergranules dependent upon the geometry of transplanting? Paddy Water Environ., 13: 433-442. DOI: 10.1007/s10333-0140461-z

Gaudin R, Rasoamampionona B, Rabeharisoa L. 2016. Field specific difficulties for transplanted rice to cope with ammonia from a localized enriched environment. Int. J. Biol. Chem. Sci., 10(5): 19541960. DOI: http://dx.doi.org/10.4314/ijbcs.v10i5.1

Kapoor V, Singh U, Patil SK, Magre H, Shrivastava LK, Mishra VN, Das RO, 
Samadhiya VK, Sanabria J, Diamond R. 2008. Rice growth, grain yield, and floodwater nutrient dynamics as affected by nutrient placement method and rate. Agron. J., 100: 526-536. DOI: 10.2134/agronj2007.0007

Koudjega K, Ablede KA, Lawson IYD, Abekoe MK, Owusu-Bennoah E, Tsatsu DK. 2019. Reducing ammonia volatilization and improving nitrogen use efficiency of rice at different depths of urea supergranule application. Communications in Soil Science and Plant Analysis, 50(8): 974-986. DOI: 10.1080/00103624.2019.1594880

Nye PH. 1972. The measurement and mechanism of ion diffusion in soils. VIII. A theory for the propagation of changes of pH in soils. J. Soil Sci., 23(1): 82-92.

Pelster DE, Watt D, Strachan IB, Rochette P, Bertrand N, Chantigny MH. 2019. Effects of initial soil moisture, clod size, and clay content on ammonia volatilization after subsurface band application of urea. J. Environ. Qual., 48: $549-558 . \quad$ DOI: 10.2134/jeq2018.09.0344

Ponnamperuna FN. 1972. The chemistry of submerged soils. Adv. Agron., 24: 29-96.

Rachhpal-Singh, Kirk GJD. 1993. A model for predicting the fate of nitrogen fertilizer in lowland rice fields. I. Theory. J. Soil Sci., 44: 271-283.
Rochette P, Angers DA, Chantigny MH, Gasser MO, MacDonald JD, Pelster DE, Bertrand N. 2013. Ammonia volatilization and nitrogen retention: How deep to incorporate urea? $J$. Environ. Qual., 42: 1635-1642. DOI: 10.2134/jeq2013.05.0192

Sander R. 2015. Compilation of Henry's law constants (version 4.0) for water as solvent. Atmos. Chem. Phys., 15: 43994981. DOI: $10.5194 / \mathrm{acp}-15-4399-2015$

Yao Y, Zhang M, Tian Y, Zhao M, Zhang B, Zhao M, Zeng K, Yin B. 2018. Urea deep placement for minimizing $\mathrm{NH}_{3}$ loss in an intensive rice cropping system. Field Crops Res., 218: 254-266. DOI: 10.1016/j.fcr.2017.03.013

Yoshida S. 1981. Fundamentals of rice crop science. IRRI (ed): Los Banos, Philippines.

Zhang M, Yao Y, Zhao M, Zhang B, Tian Y, Yin B, Zhu Z. 2017. Integration of urea deep placement and organic addition for improving yield and soil properties and decreasing $\mathrm{N}$ loss in paddy field. Agric. Ecosyst. Environ., 247: 236-245. DOI: 10.1016/j.agee.2017.07.001. 